\title{
Long-term interaction of coal combustion by-product with water
}

\author{
${ }^{1}$ Maria Żygadło, ${ }^{2}$ Magdalena Woźniak \\ ${ }^{1}$ Kielce University of Technology, Department of Civil and Environmental Engineering, Chair of Environmental \\ Engineering and Protection, Al. 1000-lecia P.P. 7, 25-314 Kielce, Poland, e-mail: zygadlo@tu.kielce.pl \\ ${ }^{2}$ Kielce University of Technology, Department of Civil and Environmental Engineering, Al. 1000-lecia P.P. 7, \\ 25-314 Kielce, Poland
}

\begin{abstract}
A terrestrial disposal of the fly ash has been regarded as a potential source of contamination due to the enrichment and surface association of trace elements in ash particles. In laboratory conditions the leaching of soluble components existing in ashes proceeds in a different way than in land deposits.

On the landfill site coal combustion by-products are under the pressure of atmosphere agents, especially water, sun and rain activity (drying and wetting alternately), freeze/thaw (in cold climate) and gases included in the air. Also the time of exposition is an important parameter.

In the presented experiment the observed dynamics of ash solubility over a long period of time provides the evidence that in the ash-water system, a variety of precipitation processes dominate the solubility of solid mass. Simulating the weathering by the freeze/thaw test approximates the effectuated changes in ash particles structure.

The leaching of a particular ash component depends on reactions in the ash-water systems.

Solidification by compaction of the material is often favoured because of the cementitious properties of ashes being in contact with water. Secondary hydrated minerals such as ettringite, portlandite and calcite are formed during a contact with water. Calcium -silicate hydrates, aluminate-hydrates and gypsum can occur as secondary minerals. The solubility of such new phases and the solidification process determine the leaching characteristics of the ash mass.
\end{abstract}

Keywords: coal combustion by-products solubility, leachates from ash landfills, waste recycling.

\section{INTRODUCTION}

A terrestrial disposal of the coal combustion by-product has been regarded as a potential source of contamination due to the enrichment and surface association of trace elements in ash particles $^{\mathbf{1 -}}$.

For ash in outdoor emplacement, where the long-term interaction of potentially toxic elements with surface water or groundwater systems may be of concern, it also depends on the degree of weathering and the possible formation of secondary minerals. There are many parameters influencing the elements leaching from coal ashes ${ }^{9-13}$.

Leaching tests are used to elucidate the mobility of certain elements in soils, industrial wastes and other materials, and to reveal the distribution of the elements in the materials ${ }^{14-17}$.

Leaching is evaluated by laboratory tests that have been accepted as a regulatory tool ${ }^{18}$, such as the US EPA TCLP Method, the JLT-46 test used by the Japanese government, the Korea Standard leaching test, the DIN 38414 -S4 test used in Germany Austria and Belgium, the AFNOR X 31-210 test (France), the test specified in Regulation 347 of the Ontario Ministry of Energy and Environment (Canada), the Australian Bottle Leaching Procedure (Australian Standard 4493.3) and Dutch tests NEN 7341 and 7343. There are also standardised European tests, including a $\mathrm{pH}$ dependence test in which leaching is at different $\mathrm{pHs}$, according to Twardowska \& Szczepańska ${ }^{19}$, ranging between 2 and 12 . The leaching tests for fly ash were described by Egemen $\&$ Yurteri ${ }^{20}$.

In the landfill combustion by-products are under the pressure of atmosphere agents, especially water, sun and rain activity (drying and wetting), freeze/thaw (in cold climate) and gases included in the air. Thus, determining a maximum elemental solubility within a relatively short time, does not provide a consistent prediction of the results of field trials. Changes in solubility caused by natural variations in ash characteristics and the reactions between the ash and its environment are not quantified with standard leaching tests ${ }^{21}$.

That is why the leaching test alone is a poor predictor of what happens in real life.

According to authors Twardowska \& Szczepańska ${ }^{19}$, leaching tests were inadequate in representing reactions such as the dissolution of amorphous phases, the formation of secondary minerals, the effect of flow conditions, weathering, the ionic strength of pore solutions and the kinetic processes.

It was also confirmed in the experiment ${ }^{22}$ that the physical property of the ash, such as particle size, is important from the environmental point of view.

When fly ash is brought into contact with water at earth surface conditions all the existing phases are unstable. They dissolve and both more and less soluble secondary phases precipitate. Despite their high solubility, some primary phases of fly ash, especially the glass and crystalline aluminosilicate particles, dissolve very slowly, which was confirmed by Readon ${ }^{23}$.

In addition, secondary hydrous aluminosilicate alteration products are very insoluble and build up ash alteration rinds on the surfaces of the primary phases. This further impedes the dissolution of the primary phases as the mass flux of ions and water between these phases and pore water, becomes diffusion-controlled, according to the model presented by Iyer \& others ${ }^{24,25}$.

Taking into consideration waste recycle imperative, the interesting point is to prove is how the landfilling stage influences the ashes properties.

\section{MATERIALS AND METHODS}

The ash from fly EC Kielce, heat power plant was sampled. The ashes taken from the hoppers of electrostatic precipitators source were cured and underwent differential expositions. Two kinds of ash samples were investigated: the ones aged during the 
period of 12 months and no aged ones. The external factors may be poorly reflected in the leaching test when combustion byproducts are deposited on the landfill site. Freeze/ thaw cycles were considered a tool helping to evaluate the impact of the weathering act on the total surface area and the chemical activity of the investigated ash. During the test the solid/liguid ratio was kept at the same level 1:2. The freezing and thawing cycles were repeated 20 times. One cycle lasting twenty four hours included:

-14 hours of freezing at minus 15 Celsius degrees,

-8 hours of thawing at room temperature $\left(20 \pm 2^{\circ} \mathrm{C}\right)$.

The structure of ash due to chemical activity can change in time. Thus it was necessary to use a reference sample. The reference samples differed from the other ones in one thing, namely the lack of exposition to freeze/thawing tests. The reference sample was cured in laboratory conditions at room temperature, but it was also exposed to $\mathrm{CO}_{2}$ activity and air humidity.

One part of ash underwent long-term treatment in conditions simulating the deposition on landfill site in real life, including: contact with water, impact of $\mathrm{CO}_{2}$ from the air, alternating temperature, freezing and thawing cycles.

The reference, wet sample, was cured in laboratory room conditions during the time equal to the first one, which underwent the freeze/thaw exposition. Both samples were examined for the leaching ability in order to estimate the influence of frost and thawing cycles.

The behaviour of the samples cured in different conditions was compared by the chemical analysis of extracts, morphology structure.

Chemical analyses of the extracts were conducted after 5, 10, 15 and 20 freeze/thaw cycles (Fig. 1, 2). The leaching procedure used in this study was based on the work by Łaczny ${ }^{26}$. The leaching tests in our research involved the extraction procedure with distillate water as the leaching medium. Dry ash was mixed with distillate water (solid:liquid 1:100 by dry weight). To obtain the extract, a certain amount of fly ash was agitated in glass jars containing $100 \mathrm{ml}$ of distilled water, and the jars were shaken for 8 hours. All glass jars were put in laboratory shaker. The temperature was controlled $\left(20^{\circ} \pm 1\right) \mathrm{C}$ during all the extraction procedures.

After the required period of agitation had elapsed, the extracts were filtered through the filter paper. All the extractions were carried out as triplicate runs.

The volume of the effluent was measured and a sample was taken aside for further investigations.

In the resulting elutes the $\mathrm{pH}$ and conductivity were analysed.

Conductivity was measured by means of the conductometer according to The Polish Standard PN-77/C-04542 with a controller type HJ 8819 N (HANNA instruments). In Figures 1, 2 each point means the result of 3 separate sample investigations. The $\mathrm{pH}$ examination was made according to the Polish standard PN-91/C-04540/01 by a potentiometer method using the $\mathrm{pH}$ controller (type OP-208/1).

\section{RESULTS}

According to figures $1 \mathrm{a}$ ) and b) the solubility of ash measured by the conductivity test during the time decreases for both the reference and the frozen sample, but the slope in the case of the ash undergoing freezing/ thawing tests is conspicuous (distinct). It means that the frezeeing/thawing test decreased the solubility of ash grains.

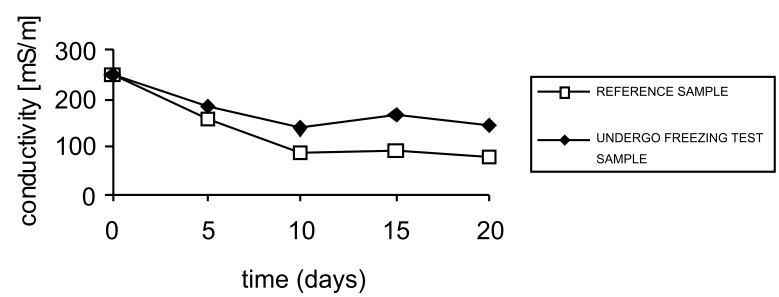

a)

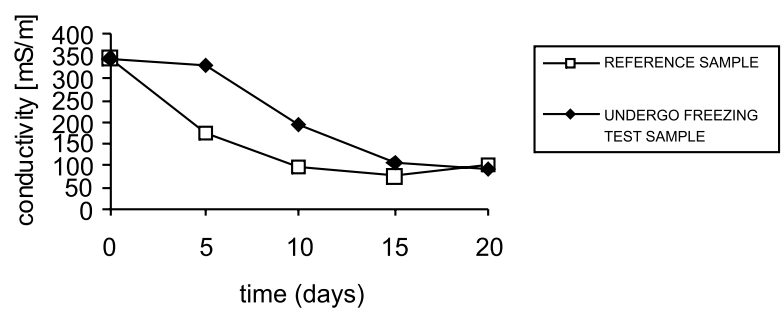

b)

Figure 1. Influence of time in the conductivity in the effluent: a) the samples aged 12 months , b) the samples not aged

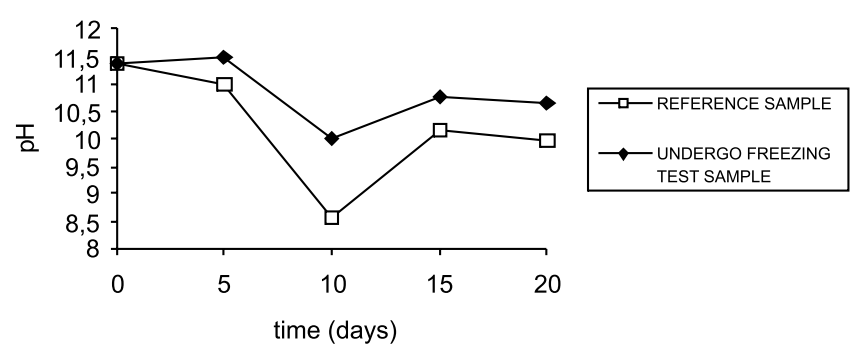

a)

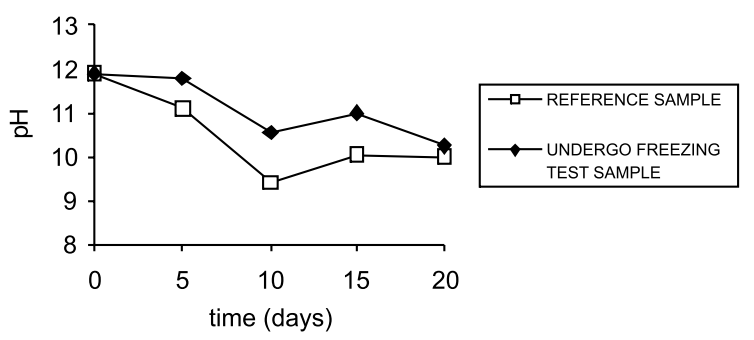

b)

Figure 2. PH presentation in the leaches from ash: a) the samples aged 12 months, b) the samples not aged

The analysis of $\mathrm{pH}$ change in the samples shows that in both cases alkalinity is decreasing. The most distinguished slope is observed after 10 cycles. It can also be observed that in the frozen ash the sample $\mathrm{pH}$ decrease is lower than in the comparable - reference sample.

It was confirmed that freezing/thawing tests accelerate the processes, normally taking place in the ash-water system. The most conspicuous changes in the examined parameters were observed after 10 cycles. The decrease of ashes solubility and $\mathrm{pH}$ during the period of investigation provide the arguments confirming the cementitious processes.

The results of SEM examination are illustrated in Figures 3 -4 . They confirmed the impact of the long-time test and the freezing/ thawing test on the condition of particles in ash. It can be seen in the morphology of the particles (Fig. 3,4). 


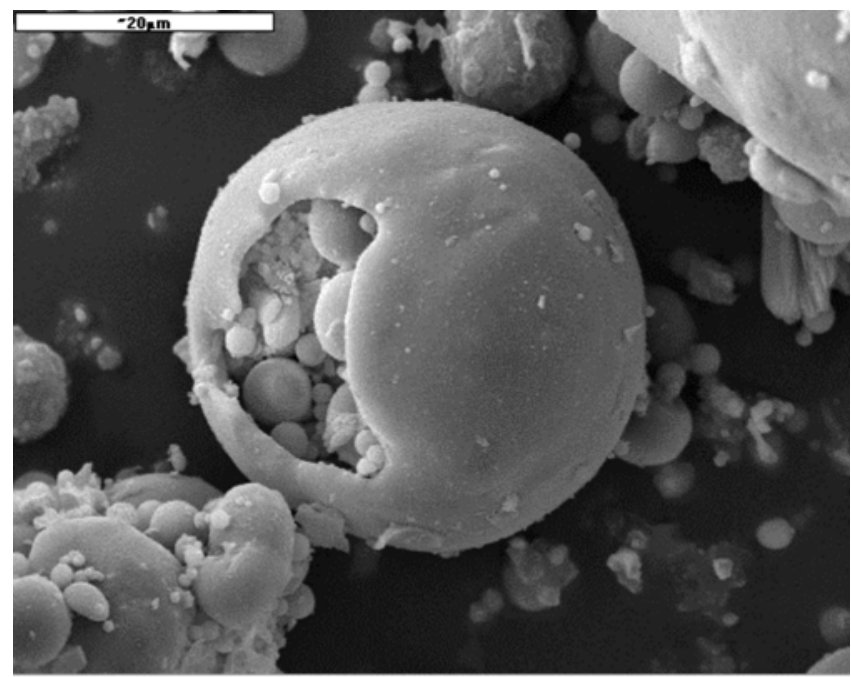

a)

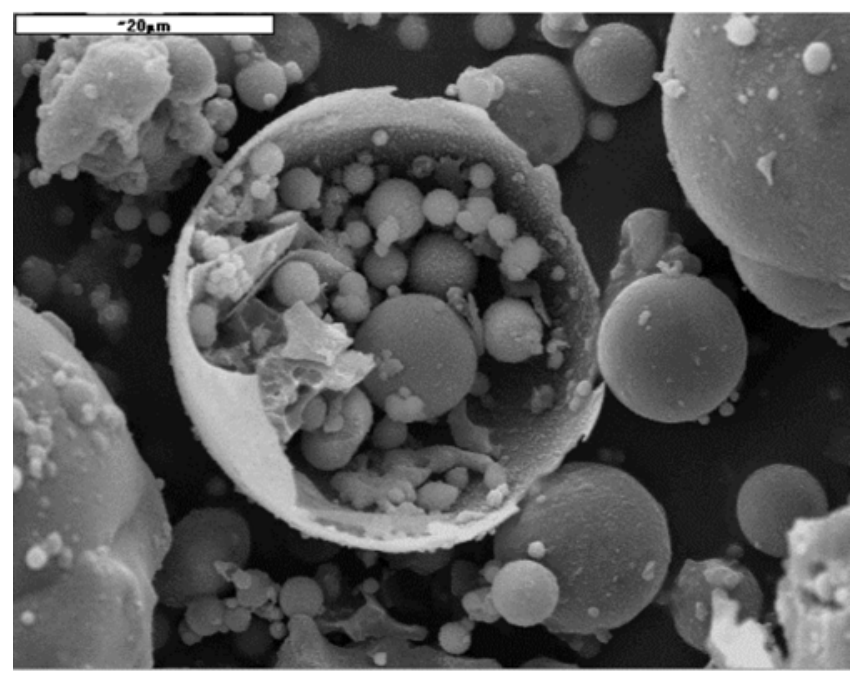

b)

Figure 3. SEM. Magnitude 2000x. The view of: a) reference ash sample , b) ash sample undergoes 20 cycles of the freezing/thawing test

\section{DISCUSSION}

In the presented experiment the observed dynamics of ash solubility over a long period of time provides the evidence that in the system ash-water, a variety of precipitation processes dominate the solubility of the solid mass. Simulating the weathering by the freeze/thaw test approximates the effectuated changes in the ash particles structure.

The leaching of a particular ash component depends on the reactions in the ash-water systems.

Solidification by compaction of the material is often favoured because of cementation properties of ashes being in contact with water and decreasing the conductivities observed during time (Fig.1). Calcium -silicate hydrates, aluminate-hydrates and gypsum can occur as secondary minerals ${ }^{22}$. The solubility of such new phases and the solidification process determine the leaching of the ash mass.

Secondary hydrated minerals such as ettringite, portlandite and calcite are formed during a contact with water. Ettringite is the compound of calcium, aluminum sulphate, with the nominal composition $\left[\mathrm{Ca}_{6} \mathrm{Al}_{2}\left(\mathrm{SO}_{4}\right)_{3}(\mathrm{OH})_{12} \cdot 26 \mathrm{H}_{2} \mathrm{O}\right]$. The presence of ettringite is the result from the dissolution of $\mathrm{Ca}$ and $\mathrm{Al}$ - containing minerals and subsequent reaction between such phases according to the equation:

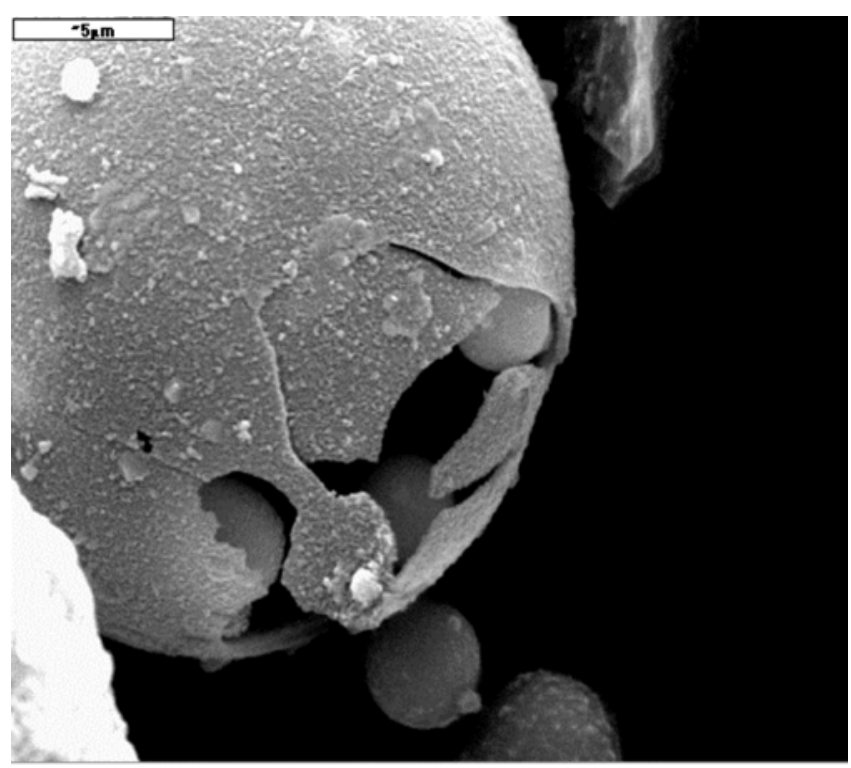

a)

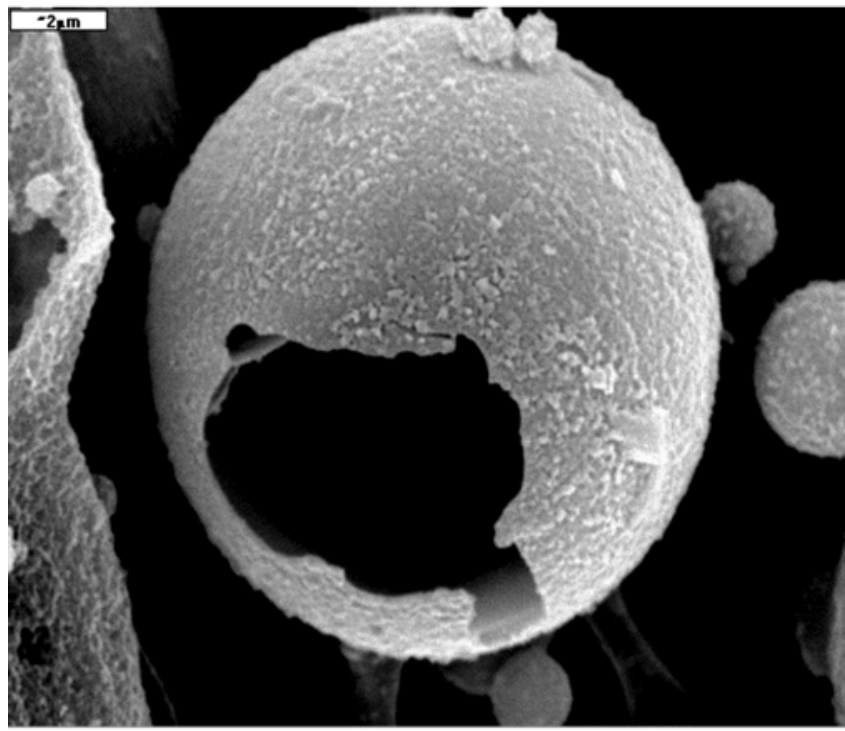

b)

Figure 4. The view of a particular grain in the ash sample after 20 freezing/thawing cycles of the freezing/ thawing test. Magnitude respectively: a) 5000x and b) $7500 \mathrm{x}$

$6 \mathrm{Ca}^{+2}+2 \mathrm{Al}^{+3}+3 \mathrm{SO}_{4}{ }^{2-}+38 \mathrm{H}_{2} \mathrm{O} \leftrightarrow 12 \mathrm{H}^{+}+$

$\mathrm{Ca}_{6} \mathrm{Al}_{2}\left(\mathrm{SO}_{4}\right)_{3}(\mathrm{OH})_{12} \cdot 26 \mathrm{H}_{2} \mathrm{O}$

For ettringite formation excess water is necessary. Chemical equilibrium calculations have shown that ettringite is not stable at a $\mathrm{pH}$ below 10.5 .

The portlandite $\left(\mathrm{Ca}(\mathrm{OH})_{2}\right.$ formed by hydration of $\mathrm{CaO}$ subsequently reacts with $\mathrm{CO}_{2}$ in air penetrating the wetted ash mass according to the reaction:

$\mathrm{Ca}(\mathrm{OH})_{2(\mathrm{cr})} \rightarrow \mathrm{Ca}(\mathrm{OH})_{2(\mathrm{aq})}+\mathrm{CO}_{2} \rightarrow \mathrm{CaCO}_{3(\mathrm{cr})}+\mathrm{H}_{2} \mathrm{O}(2)$

Both compounds, the portlandite and the carbon dioxide are dissolved in the pore fluid of the wetted ash and the calcium carbonate crystallises from the solution. The transformation of portlandite into calcite reduces the high $\mathrm{pH}$ and it was observed in Fig 2. This phenomenon is important as it reduces the risk of negative effects on the environment around the combustion by-products deposits. Another advantage of ash ability is extensive substitutions of ions in the ettringite structure, which is supposed to be one of the reasons for the retention of metals in wetted waste materials. 
In our experiment comparing of grains surface before and after ageing process confirms the reaction with water. On outside particular grain surface (Fig 4.) the newly formed products can be seen. The observation of grain morphology change (Fig.3,4), made in the presented experiment, is conformable to that obtained during a field experiment, described by Cheerarot \& Jaturapitakkul ${ }^{27}$. The authors ${ }^{27}$ concluded that fly ashes disposed from 6 to 24 month have both different particle sizes and chemical composition. It was observed that some particles of the disposed fly ashes were irregular and porous, due to weathering. It was asserted that fly ashes from the ones deposited over 6 or 24 months, should not be used as a pozzolanic material since it resulted in the low compressive strength of the mortar. Thus the ashes taken from landfills possess different attributes than those taken immediately from precipitators.

\section{CONCLUSIONS}

From our observation it can be confirmed that weathering is the reason of individual grain destruction. As a result grains are more reactive and more reaction products encircle the particular grain, inhibiting the solution process.

The SEM pictures of ash particles tested after 5 to 10 of freeze /thaw cycles were comparable with those observed by Cheerarot \& Jaturapitakkul ${ }^{27}$ for the ashes affected by weathering factors press for a period 24 months. The SEM pictures of the ashes undergoing field studies, compared with the observed indications of spherical particles destruction in field tests and in our experiments, proved to be the same.

Thus, it was confirmed that the freeze/ thaw test can be used as a helpful tool to conduct a short time investigation on the behaviour of the combustion by-product deposited on landfill and subjected to weathering. This test can simulate both the field conditions press and climate impact in real life.

\section{LITERATURE CITED}

1. Choi, S.K., Lee, S., Song, Y.K. \& Moon, H.S. (2002). Leaching characteristics of selected Korean fly ashes and its implications for the groundwater composition near the ash mound, Fuel, 81, 1083 - 1090. http://www.fuelfirst.com

2. Fitianos, K., Tsanikiidi, B. \& Voundrias, E. (1998). Leacibility of heavy metals in Greek fly ash from coal combustion, Environ. Int., 24, 477 - 486.

3. Jankowski, J., Ward, C.R., French, D. \& Groves, S. (2006). Mobility of trace elements from selected Australian fly ashes and its potential impact on aquatic ecosystems, Fuel, 85, 243 - 256.

4. Mehtap, P. et al. (2006). Acid leaching of ash and coal: Time dependence and trace element occurrences, Int. J. Miner. Process, 79, 27 - 41. http://www.elsevier.com/locate/ijminpro

5. Miravet, R., Fer Lopez-Sanchez, J. \& Rubio, R. (2006). Leachability and analytical speciation of antimony in coal fly ash, Analytica Chemica Acta, 576, 200 - 206. http:// www.sciencedirect.com, http://www.elsevier.com.locate.aca

6. Mudd, G.M. \& Kodikara, J. (2000). Field studies of the leachability of aged brown coal ash, J. Hazardous Materials, 159 - 192. http://www.elsevier.nl/locate/jhazmat

7. Querol, X. et al., (1996). Mobility of trace elements from coal and combustion wastes, Fuel, 75, No 7, $821-838$.

8. Querol, X.,et al. (2001), Extraction of soluble major and trace elements from fly ash in open and closed leaching systems, Fuel, 80, 801 - 813. http://www.elsevier.com/locate/ fuel

9. Oter-Rey, J. et al. (2005). Influence of several experimental parameters on As and Se leaching from coal fly ash samples, Analytica Chemica Acta, 531, 299 - 305.
10. Paul, M., Seferinoglu, M., Aycik, G.A., Sastrom, A., Smith, M.L. \& Paul,J. (2006). Acid leaching of ash and coal, Time dependence and trace element occurrences, Int. J. Miner. Process, 79, 27 - 41.

11. Praharaj, T., Powell, M.A., Hart, B.R. \& Tripathy, S. (2002). Leachability of elements from sub-bituminous coal fly ash from India, Environmental International, 27, 609 - 615. http://www.elsevier.com/locate/envint

12. Wang, J. et al. (2006). Impacts of $\mathrm{pH}$ and ammonia on the leaching of $\mathrm{Cu}(\mathrm{II})$ and $\mathrm{Cd}(\mathrm{II})$ from coal fly ash, Chemosphere 64, 1892 - 1898. http://www.elsevier.com/locate/ chemosphere

13. Xu, M., Yan, R. \& Zheng, Ch., et al. (2003). Status of trace element emission in coal combustion process: a review, Fuel Processing Technology, 85, 215 - 237.

14. Hasset, D.J., Pflughoeft-Hassett, D.F. \& Heebink, L.V. (2005). Leaching of CCBs: observations from over 25 years of research, Fuel 84, 1378 - 1383. http://www.sciencedirect.com

15. Seidel, A. \& Zimmels, Y. (1998). Mechanism and kinetics of aluminium and iron leaching from coal fly ash by sulphuric acid, Chemical Engineering Science, 55, 22, 3835 3852. PII; S009-2509(98)00201-2

16. Stefanowicz, T., Napieralska-Zagozda, S., Osińska, M. \& Szwankowski, S. (1994). The leacheabilty test as a criterion of hazardousness of deposited industrial wastes - in Polish, Test wymywalności zanieczyszczeń jako kryterium oceny szkodliwości składowanych odpadów przemysłowych, Archiwum Ochrony Środowiska, nr $1-2$,

17. Ugurlu, A. (2004), Leaching characteristics of fly ash, Environmental Geology, 46, 890 - 895. DOI 10.1007/S))254004-1100-6

18. Reijnders, L. (2005). Disposal, uses and treatments of combustion ashes: a review, Resources, Conservation and Recycling, 43, 313 - 336. http://www.elsevier.com/locate/resource

19. Twardowska, I. \& Szczepanska, J. (2002). Solid waste: terminological and long-term environmental risk assessment problems exemplified in a power plant fly ash study, The Science of the Total Environment, 285, 29 - 51. http:// www.elsevier.com/locate/scitoenv

20. Egemen, E. \& Yurteri, C. (1996). Regulatory leaching tests for fly ash: a case study, Waste Management \& Research, $14,43-50$.

21. Kim, A. \& Kazonich, G. (2004). The silicate / monosilicate distribution of metals in fly ash and its effect on solubility, Fuel, 83, 2285 - 2292. http://www.fuelfirst.com

22. Steenari, B.M., Schelander, S. \& Lindqvist, O. (1999). Chemical and leaching characteristics of ash from combustion of coal, peat and wood in a $12 \mathrm{MW}$ CFB - a comparative study, Fuel, 78, 249 - 258.PII-S0016-2361(98)00137-9

23. Reardon, E.J. et al. (1995). Determining controls on element concentrations in fly ash leachate, Waste Management \& Research, 13, 435 - 450.

24. Iyer, R. (2002). The surface chemistry of leaching coal fly ash, J. Hazardous Materials B 93, 321 - 329. http:// www.elsevier.com/locate/jhazmat

25. Iyer, R.S., Stanmore, B.R. \& Pullammanappallil, P.C. (2001). The role of the diffuse double layer in leaching of calcium from the surface of fly ash particles, Colloids and Surfaces A: Physicochemical and Engineering Aspects, 177, 69 $-74$.

26. Łączny, J.M. (1979). The solubility of ash in water - in Polish, Rozpuszczalność popiołów lotnych w wodzie, Energetyka, 12, 1979, 485 - 486. http://www.elsevier.nl/locate/ colsurfa

27. Cheerarot, A. \& Jaturapitakkul, R. (2004). A study of disposed fly ash from landfill to replace Portland cement, Waste Management 24, 701 - 709. http://www.elsevier.com/ locate/wasman 